\title{
Study and application of heat preservation and crack control measures for gravity dam in severe cold regions
}

\author{
Huaizhi Zhang ${ }^{\mathrm{a},{ }^{,}}$, Baolong $\mathrm{Wu}^{\mathrm{b}}$, Fan $\mathrm{Bai}^{\mathrm{c}}$ and $\mathrm{Ke} \mathrm{Li}^{\mathrm{d}}$ \\ Powerchina Beijing Engineering Corporation Limited, Chaoyang District, Beijing, China \\ ahuaizhi1983@163.com, bwubaol@bhidi.com, cbaif@bhidi.com, dik@bhidi.com
}

Keywords: Overwintering layer, Simulation analysis, Heat preservation measures, Crack control measures

For the rest of the paper, please use Times Roman (Times New Roman) 12

Abstract. During the concrete pouring process, the long downtime would weaken the bonding strength between old and new concrete layers. The bonding parts would like to form horizontal cracks, especially winter intermittent surface in the severe cold region, of which cracks would easily propagates from surface to inside, even through the concrete, seriously affects the security of dam. This paper takes the sediment storage dam of the down reservoir of Hohhot pumped storage power station as a case, the heat preservation and crack control measures of overwintering area have been analyzed. To avoid the occurrence of cracks of overwintering layer during winter and according to the site or local material, this paper draws up two schemes. Scheme I: taking the water storage to preserve heat; Scheme II: $5 \mathrm{~cm}$ thick polystyrene insulation (which can be used as temporary heat preservation measures normally) and $15 \mathrm{~cm}$ thick straw and $30 \mathrm{~cm}$ thick corn straw +2 layer water proof cloth. According to the simulation of the two schemes, the results shows that: scheme I exist "chilling effect" and the local stress is too high, while both the temperature and stress conditions of scheme II meet the requirements for overwintering. After overwintering period, the construction of the dam continues. To ensure the quality of concrete near the overwintering layer, the upper and lower temperature difference and the highest temperature should be controlled and the crack prevention of concrete should be took. According to the construction conditions, the similar experience in project site and relevant requirements of crack prevention, this paper makes three schemes. Scheme I: control the upper pouring new concrete pouring layer thickness, pouring temperature, intermittent, water and temporary ins ulation and return to construction in late-April; Scheme II: Taking all measures of Scheme I and heating the old concrete layer; Scheme III: Taking all measures of Scheme II and return to construction in mid-May. The simulation results show that Scheme I occurs upper and lower temperature difference and the existence of tensile stresses exceed the standard phenomenon, while Scheme II and III are feasible. After two consecutive 2011 2013 overwinters test, the implementation of heat preservation and crack control measures of overwintering layer concrete of the sediment storage dam of the down reservoir of Hohhot pumped storage power station works well, which can provide a reference for the similar problems in other engineering.

\section{Introduction}

Generally gravity dams of large and medium hydropower stations need more than one year to complete construction because of its large volume of concrete. In severe cold regions due to weather restrictions, winter should be shut down intermittently, resulting in bonding issues between new and old concrete layers and overwintering layer issues. During the concrete pouring process, the long downtime would weaken the bonding strength between old and new concrete layers. The bonding parts would like to form horizontal cracks, especially winter intermittent surface in the severe cold region. When the horizontal cracks occur on the upstream surface, reservoir impoundment resulting vertical compressive stress below the seam internal water pressure, cracks would easily extended to the downstream face of the dam, causing hydraulic fracture ${ }^{[1]}$, seriously affect the security of dam. When the horizontal cracks occur in the water level fluctuation zone in severe regions, it is easily to produce concrete freeze-thaw damage, seriously affect the life of the dam. This 
paper takes the sediment storage dam of the down reservoir of Hohhot pumped storage power station as a case, the heat preservation and crack control measures for gravity in severe cold regions have been analyzed.

Hohhot pumped storage power station locates in the area of DaQing mountain, northeast of Hohhot City in Inner Mongolia Autonomous Region, where belongs to the severe cold area, climate has the characteristics of long winter and short summer, winter and summer changes dramatically, large temperature difference, high evaporation. The winter is long and cold, permafrost period of up to five months. In dam area the annual average temperature is $6.3^{\circ} \mathrm{C}$, the monthly mean temperature of July is $22.4^{\circ} \mathrm{Cand}-12.2^{\circ} \mathrm{C}$ in January, the extreme maximum temperature is $38.5^{\circ} \mathrm{C}$, the extreme minimum temperature is $-32.8^{\circ} \mathrm{C}$, the maximum wind speed is $20.0 \mathrm{~m} / \mathrm{s}$.

The project's total installed capacity is $1200 \mathrm{MW}$, and the size belongs large (1) type. The sediment storage dam of the down reservoir is a RCC gravity dam which used the "gold silver package" approach: 2.0 m impermeable layer upstream and $3.0 \mathrm{~m}$ protective layer downstream and $1.5 \mathrm{~m}$ foundation cushion layer are all of normal concrete. Crest elevation is $1401 \mathrm{~m}$, the maximum height of $58 \mathrm{~m}$, crest length of $200 \mathrm{~m}$, the largest dam bottom width of $58 \mathrm{~m}$. The dam without longitudinal joints, only transverse joints, is divided into 12 sections, in addition to the right bank 1\# dam section and the left bank 10\# 12\# dam sections transverse joint space is $14.0 \mathrm{~m}$, the rest of the dam is $18.0 \mathrm{~m}$.

\section{Basic information}

The cushion concrete (elevation 1343 1344.5m) of sediment storage dam is poured in mid-July 2011, pouring temperature of $15.2^{\circ} \mathrm{C} \sim 20.5^{\circ} \mathrm{C}$, the average atmospheric temperature of $24^{\circ} \mathrm{C}$. The normal concrete and roller compacted concrete of elevation 1344.5 1347.5m are poured in late September, pouring temperature of $12.4^{\circ} \mathrm{C} \sim 17^{\circ} \mathrm{C}$, the average atmospheric temperature of $13.4^{\circ} \mathrm{C}$. The normal concrete and roller compacted concrete of elevation 1347.5 1351.0m are poured in mid-October, pouring temperature of $7^{\circ} \mathrm{C} \sim 15.5^{\circ} \mathrm{C}$, the average atmospheric temperature of $10^{\circ} \mathrm{C}$. The normal concrete and roller compacted concrete of elevation $1351.0 \sim 1352.5 \mathrm{~m}$ are poured in late October, pouring temperature of $8^{\circ} \mathrm{C} \sim 14^{\circ} \mathrm{C}$, the average atmospheric temperature of $6.5^{\circ} \mathrm{C}$. When pouring to elevation $1352.5 \mathrm{~m}$ the construction of dam is shut down because of overwinter in early November.

The cooling water pipes are arranged to $1.0 \mathrm{~m}$ (horizontal) $\times 0.9 \mathrm{~m}$ (vertical) in cushion part, the other parts the cooling water pipes arranged $1.5 \mathrm{~m}$ (horizontal) $\times 1.5 \mathrm{~m}$ (vertical), water temperature averages 10 ${ }^{\circ} \mathrm{C}, 13 \sim 25 \mathrm{~L} / \mathrm{min}$, through the water time $20 \mathrm{~d}$. In late October $1351.5 \sim 1352.5 \mathrm{~m}$ elevation pouring concrete is not disposed of cooling pipes.

In mid-November 2011, the construction of the upstream and downstream dam face permanent insulation measures is completed: the upstream surface of $5 \mathrm{~cm}$ thick polyurethane + Rock Backfill, the downstream surface by spraying $8 \mathrm{~cm}$ thick polyurethane $+3 \mathrm{~cm}$ thick polyester mortar.

The concrete mix proportion of the sediment storage dam of the down reservoir is shown in table 1 .

Table 1 The main parameters of concrete mix proportion

\begin{tabular}{|c|c|c|c|c|c|}
\hline No & Position & Grade & $\begin{array}{c}\text { Cemen } \\
\mathrm{t}\end{array}$ & $\begin{array}{c}\text { Fly-as } \\
\mathrm{h}\end{array}$ & $\begin{array}{c}\text { Wate } \\
\text { r }\end{array}$ \\
\hline (1) & $\begin{array}{c}\text { Cushion and downstream of the dam site(less than elevation } 1354 \mathrm{~m}) \text {, Normal concrete, }(\mathrm{t} \text { hird } \\
\text { grade) }\end{array}$ & $\begin{array}{c}\mathrm{C}_{90} 2 \\
5\end{array}$ & $166 \mathrm{~kg}$ & $64 \mathrm{~kg}$ & $\begin{array}{c}104 \mathrm{k} \\
\mathrm{g}\end{array}$ \\
\hline (2) & Roller compacted concrete (third grade) & $\begin{array}{c}\mathrm{C}_{90} 1 \\
5\end{array}$ & $72 \mathrm{~kg}$ & $108 \mathrm{~kg}$ & $90 \mathrm{~kg}$ \\
\hline (3) & $\begin{array}{c}\text { Upstream and downstream of the dam site(higher than elevation } 1354 \mathrm{~m}), \text { Normal concrete, (third } \\
\text { grade) }\end{array}$ & $\begin{array}{c}\mathrm{C}_{90} 2 \\
5\end{array}$ & $227 \mathrm{~kg}$ & $57 \mathrm{~kg}$ & $\begin{array}{c}125 \mathrm{k} \\
\mathrm{g}\end{array}$ \\
\hline
\end{tabular}

According to the test data and related information ${ }^{[2][3][4]}$ of this project, thermodynamic parameters of the concrete is shown in Table 2 - Table 5. 
Table 2 Thermodynamics parameters of concrete

\begin{tabular}{|c|c|c|c|c|c|c|c|c|c|}
\hline $\begin{array}{c}\text { No } \\
\text {. }\end{array}$ & $\begin{array}{c}\text { Therma } \\
1 \\
\text { diffusivi } \\
\text { ty } \\
\alpha /\left(\mathrm{m}^{2} / \mathrm{d}\right)\end{array}$ & $\begin{array}{c}\text { Thermal } \\
\text { conductivit } \\
\mathrm{y} \lambda /(\mathrm{kJ} / \mathrm{d} \bullet \\
\left.\mathrm{m} \bullet{ }^{\circ} \mathrm{C}\right)\end{array}$ & $\begin{array}{l}\text { Specifi } \\
\mathrm{c} \text { heat } \\
c /(\mathrm{kJ} / \\
\left.\mathrm{kg} \bullet{ }^{\circ} \mathrm{C}\right)\end{array}$ & $\begin{array}{l}\text { Heat transfer } \\
\text { coefficient } \\
\beta /(\mathrm{kJ} /(\mathrm{m} 2 \bullet \mathrm{d} \bullet \\
\left.\left.{ }^{\circ} \mathrm{C}\right)\right)\end{array}$ & $\begin{array}{c}\text { Linear } \\
\text { expansio } \\
\mathrm{n} \\
\text { coefficie } \\
\mathrm{nt} \alpha \\
\left(10^{-6} /{ }^{\circ} \mathrm{C}\right)\end{array}$ & $\begin{array}{c}\text { Densit } \\
\mathrm{y} \\
\rho /(\mathrm{kg} / \\
\left.\mathrm{m}^{3}\right)\end{array}$ & $\begin{array}{l}\text { Poisso } \\
\text { n's } \\
\text { ratio } \\
v\end{array}$ & $\begin{array}{c}\text { Adiabatic temperature } \\
\text { rise }\left({ }^{\circ} \mathrm{C}\right)\end{array}$ & $\begin{array}{l}\text { Elastic modulus } \\
\qquad \mathrm{E} / \mathrm{GPa}\end{array}$ \\
\hline (1) & 0.077 & 248 & 1.03 & 960 & 7.95 & 2510 & 0.167 & $\theta(\tau)=30 \tau /(2.0+\tau)$ & $E=38\left(1-e^{-0.5 \tau^{0.39}}\right)$ \\
\hline (2) & 0.086 & 251 & 0.97 & 960 & 7.69 & 2510 & 0.167 & $\theta(\tau)=16 \tau /(4.0+\tau)$ & $E=33\left(1-e^{-0.52 \tau^{0.5}}\right)$ \\
\hline (3) & 0.074 & 243 & 1.04 & 960 & 8.14 & 2470 & 0.167 & $\theta(\tau)=40 \tau /(1.5+\tau)$ & $E=43\left(1-e^{-0.5 \tau^{0.36}}\right)$ \\
\hline
\end{tabular}

Table 3 The maximum allowable tensile stress of concrete

\begin{tabular}{|c|c|c|c|c|}
\hline No. & Age (d) & Elastic modulus (MPa) & Ultimate tensile value $(\times 10-6)$ & Allowable tensile stress $(\mathrm{MPa})$ \\
\hline \multirow{4}{*}{ (1) } & 7 & 24.4 & 73 & 1.08 \\
\hline & 28 & 33.5 & 86 & 1.75 \\
\hline & 90 & 36.1 & 91 & 1.99 \\
\hline & 180 & 37.1 & 93 & 2.09 \\
\hline \multirow{4}{*}{ (2) } & 7 & 24.4 & - & - \\
\hline & 28 & 27.8 & 75 & 1.26 \\
\hline & 90 & 30.7 & 86 & 1.6 \\
\hline & 180 & 30.7 & 89 & 1.66 \\
\hline \multirow{4}{*}{ (3) } & 7 & 27.2 & 82 & 1.35 \\
\hline & 28 & 38 & 93 & 2.14 \\
\hline & 90 & 38.8 & 96 & 2.26 \\
\hline & 180 & 39.8 & 97 & 2.34 \\
\hline
\end{tabular}

Table 4 The maximum allowable vertical stress of concrete

\begin{tabular}{|c|c|c|c|}
\hline No. & Age (d) & Axial tensile strength (MPa) & Allowable vertical stress (MPa) \\
\hline \multirow{4}{*}{ (1) } & 7 & 1.47 & 0.59 \\
\hline & 28 & 2.79 & 1.12 \\
\hline & 90 & 3.14 & 1.26 \\
\hline & 180 & 3.41 & 1.36 \\
\hline \multirow{4}{*}{ (2) } & 7 & - & - \\
\hline & 28 & 1.37 & 0.55 \\
\hline & 90 & 2.48 & 0.99 \\
\hline & 180 & 2.73 & 1.09 \\
\hline \multirow{4}{*}{ (3) } & 7 & 1.72 & 0.69 \\
\hline & 28 & 3.1 & 1.24 \\
\hline & 90 & 3.49 & 1.4 \\
\hline & 180 & 3.79 & 1.52 \\
\hline
\end{tabular}

The overwintering layer surface (elevation $1352.5 \mathrm{~m}$ ) of sediment storage dam is in strong constrained zones, that concrete temperature control criteria is shown in Table 5. 
Table 5 Concrete temperature control criteria

\begin{tabular}{c|c|c|c}
\hline Name & Cushion concrete & RRC of inside & Normal concrete of upstream and downstream \\
\hline Maximum allowable temperature & $28.5^{\circ} \mathrm{C}$ & $23^{\circ} \mathrm{C}$ & $28.5^{\circ} \mathrm{C}$ \\
\hline Upper and lower allowable temperature difference & $16^{\circ} \mathrm{C}$ & $15^{\circ} \mathrm{C}$ & $16^{\circ} \mathrm{C}$ \\
\hline Inside and out side temperature difference & $20^{\circ} \mathrm{C}$ & $20^{\circ} \mathrm{C}$ & $20^{\circ} \mathrm{C}$ \\
\hline Insulation standard $\mathrm{KJ} /\left(\mathrm{m} 2 \cdot \mathrm{d} \cdot{ }^{\circ} \mathrm{C}\right)$ & $\leq 38.8^{\circ} \mathrm{C}$ & $\leq 38.8^{\circ} \mathrm{C}$ & $\leq 38.8^{\circ} \mathrm{C}$ \\
\hline
\end{tabular}

\section{Simulation and analysis of insulation measures for overwintering layer}

When the sediment storage dam of the down reservoir of Hohhot pumped storage power station is poured to elevation $1352.5 \mathrm{~m}$, the construction of dam is shut down.

To avoid the occurrence of cracks of overwintering layer during winter and according to the site or local material, this paper draws up two schemes. Scheme I: taking the water storage to preserve heat; Scheme II: $5 \mathrm{~cm}$ thick polystyrene insulation $+15 \mathrm{~cm}$ thick straw and $30 \mathrm{~cm}$ thick corn straw +2 layer water proof cloth.

According to the formula (1) ${ }^{[5]}$, surface equivalent heat transfer coefficient of concrete after insulation is calculated: Scheme I is $34 \mathrm{KJ} /\left(\mathrm{m} 2 \bullet \mathrm{d} \bullet{ }^{\circ} \mathrm{C}\right)$; Scheme II is $32 \mathrm{KJ} /\left(\mathrm{m}^{2} \bullet \mathrm{d} \bullet{ }^{\circ} \mathrm{C}\right)$. The results show that both the insulation schemes meet the requirements.

$$
\beta=1 /\left(\frac{1}{\beta_{0}}+\frac{\sum h_{i}}{\lambda_{i} k_{1} k_{2}}\right)
$$

$\lambda_{i}$ - thermal conductivity of insulation materials, water: $2.1 \mathrm{KJ} /(\mathrm{m} \bullet \mathrm{h} \bullet \mathrm{k})$, ice: $2.2 \mathrm{KJ} /(\mathrm{m} \bullet \mathrm{h} \bullet \mathrm{k})$, straw and corn straw: $0.51 \mathrm{KJ} /(\mathrm{m} \bullet \mathrm{h} \bullet \mathrm{k})$, polystyrene insulation: $0.1 \mathrm{KJ} /(\mathrm{m} \bullet \mathrm{h} \bullet \mathrm{k})$;

$\beta_{0} \longrightarrow$ surface equivalent heat transfer coefficient of concrete without insulation, $40 \mathrm{KJ} /(\mathrm{m} \cdot \mathrm{h} \cdot \mathrm{k})$;

$h_{i} \_$insulation thickness, m;

$k_{1} \longrightarrow$ wind speed correction factor, 1.3;

$k_{2}$ - humidity correction factor, wet materials is $3 \sim 5$, dry materials is 1 .

According to the 2011 record of dam concrete construction and concrete thermodynamic parameters, the heat preservation Schemes I\&II are simulated by the 3-D finite element. The results are been shown in Table 6 and Table 7.

Table 6 Temperature results during the winter

\begin{tabular}{|c|c|c|c|c|}
\hline Scheme & \multicolumn{2}{|c|}{ I } & \multicolumn{2}{|c|}{ II } \\
\hline Place & $\begin{array}{c}\text { center of } \\
\text { overwintering layer }\end{array}$ & $\begin{array}{c}\text { boundary of } \\
\text { overwintering layer }\end{array}$ & $\begin{array}{c}\text { center of } \\
\text { overwintering layer }\end{array}$ & $\begin{array}{c}\text { boundary of } \\
\text { overwintering layer }\end{array}$ \\
\hline The min temperature & $2.7^{\circ} \mathrm{C}$ & $1.3^{\circ} \mathrm{C}$ & $4.8^{\circ} \mathrm{C}$ & $3.3^{\circ} \mathrm{C}$ \\
\hline The max temperature & $17^{\circ} \mathrm{C}$ & $17^{\circ} \mathrm{C}$ & $17.5^{\circ} \mathrm{C}$ & $17.5^{\circ} \mathrm{C}$ \\
\hline Inside and outside temperature difference & $14.3^{\circ} \mathrm{C}$ & $15.7^{\circ} \mathrm{C}$ & $12.7^{\circ} \mathrm{C}$ & $14.2^{\circ} \mathrm{C}$ \\
\hline Inside and out side temperature control standards & $\leq 20^{\circ} \mathrm{C}$ & $\leq 20^{\circ} \mathrm{C}$ & $\leq 20^{\circ} \mathrm{C}$ & $\leq 20^{\circ} \mathrm{C}$ \\
\hline Meet requirements? & Yes & Yes & Yes & Yes \\
\hline
\end{tabular}


Table 7 Stress results during the winter

\begin{tabular}{|c|c|c|c|c|c|}
\hline Scheme & \multicolumn{2}{|l|}{ I } & \multicolumn{2}{|r|}{ II } & \\
\hline Place & $\begin{array}{c}\text { center of overwintering } \\
\text { layer }\end{array}$ & $\begin{array}{l}\text { center of overwintering } \\
\text { layer }\end{array}$ & $\begin{array}{c}1350.5 \sim 1352.5 \\
\mathrm{~m}\end{array}$ & $\begin{array}{c}1347.5 \sim 1350.5 \\
\mathrm{~m}\end{array}$ & $\begin{array}{c}1344.5 \sim 1347.5 \\
\mathrm{~m}\end{array}$ \\
\hline \multirow{2}{*}{$\begin{array}{c}\text { The max tensile } \\
\text { stress } \\
\text { Time }\end{array}$} & \multirow{2}{*}{$\begin{array}{l}1.2 \mathrm{Mpa} \\
\text { water storage for } \\
\text { preservation }\end{array}$} & $0.82 \mathrm{Mpa}$ & $1.2 \mathrm{Mpa}$ & $1.15 \mathrm{Mpa}$ & $1.34 \mathrm{Mpa}$ \\
\hline & & February of second year & \multicolumn{3}{|c|}{ the end of winter } \\
\hline Age & $14 \mathrm{~d}$ & $90 \mathrm{~d}$ & \multicolumn{3}{|c|}{$180 \mathrm{~d}$} \\
\hline $\begin{array}{c}\text { Allowable tensile } \\
\text { stress } \\
\end{array}$ & $0.9 \mathrm{Mpa}$ & $1.6 \mathrm{Mpa}$ & \multicolumn{3}{|c|}{$1.66 \mathrm{Mpa}$} \\
\hline Meet requirements? & No & Yes & \multicolumn{3}{|c|}{ Yes } \\
\hline
\end{tabular}

Table 6 shows that: Under the condition of Scheme I and Scheme II, the lowest temperatures of overwintering layer are higher than $0^{\circ} \mathrm{Cduring}$ the winter; Inside and outside temperature difference of the overwintering layer is $12.7^{\circ} \mathrm{C} \sim 15.7^{\circ} \mathrm{C}$, both of which meet inside and outside temperature control standards. So, both of the schemes are feasible, from the perspective of the temperature difference between inside and outside.

Analysis from the perspective of temperature stress during the winter in Table 7 shows that, under the condition of heat preservation Scheme I, the maximum tensile stress, at the time of storage, in the central portion of the overwintering layer is $1.2 \mathrm{M} \mathrm{Pa}$, which exceeds the allowable tensile stress. Therefore, Scheme I does not meet the heat preservation requirements. The reasons are that: concrete of overwintering layer is poured in late October, the heat preservation measure of water storage is completed in mid-November according to temperature environment and technical requirements. Temperature of internal concrete of the overwintering layer with the age of $14 \mathrm{~d}$ is still very high, while water temperature is only $7 \sim 8^{\circ} \mathrm{C}$, which results the "chilling effect". In addition that, because of lower anti-crack strength of early age concrete, excessive tensile stress occurs in the central portion of the overwintering layer.

Under the condition of heat preservation Scheme II, the maximum tensile stress is $0.82 \mathrm{M} P a$ which occurs at the central portion of the overwintering layer during winter, and it meets the age (90d) concrete allowable tensile stress requirements. Although the maximum tensile stress in the central portion of the overwintering layer reaches $1.15 \sim 1.34 \mathrm{MPa}$ at the end of the winter time, it meets the age (180d) concrete tensile stress requirements, whose anti-crack strength is $1.66 \mathrm{MPa}$.

According to the simulation and analyses of inside and outside temperature difference and temperature stress of Scheme I \& II: both of the schemes meet the requirements of inside and outside temperature difference, Scheme I does not meet the requirements of allowable tensile stress, while Scheme II meets.

In conclusion, Scheme II is chosen as the heat preservation measure of the overwintering layer concrete in sediment storage dam, that is $5 \mathrm{~cm}$ thick polystyrene insulation $+15 \mathrm{~cm}$ thick straw and $30 \mathrm{~cm}$ thick corn straw +2 layer water proof cloth.

\section{Simulation analysis for crack prevention measures at overwintering layer}

The concrete of sediment storage dam continued pouring after 2011 2012 overwinter. In order to ensure the quality of concrete and avoid the cracks at the bounding between new and old concrete, the crack prevention of concrete should be taken to control the upper and lower temperature difference and the highest temperature according to the technique request for temperature control of sediment storage dam. On the basis of site construction conditions, similar engineering experience and the technique request for temperature control, three different schemes of crack prevention measures at overwintering layer were decided.

Scheme I : The new concrete parameters were controlled as follows. The layer thickness was $3.0 \mathrm{~m}$, the pouring temperature was $12^{\circ} \mathrm{C}$, the layer intermittence was 7 days, the $2.5 \mathrm{~cm}$ thick expanded polystyrene board was used as temporary insulation measure. The cooling water pipes are arranged to $1.5 \mathrm{~m}$ (horizontal) $\times 1.5 \mathrm{~m}$ (vertical) in roller compacted concrete, and the cooling water pipes are arranged to $1.0 \mathrm{~m}$ (horizontal) 
$\times 0.9 \mathrm{~m}$ (vertical) in normal concrete, $1 \mathrm{~m}$ far from the dam surface. The groundwater that temperature range from $8^{\circ} \mathrm{C}$ to $10^{\circ} \mathrm{C}$ was used as cooling water. The cooling water flow was controlled to be $40 \mathrm{~L} / \mathrm{min}$ after concrete pouring 4 5 days, then the water flow decrease to 18 20 L/min until concrete pouring 18 20 days, and return to construction in late-April.

Scheme II: Taking all measures of Scheme I and heated the old concrete layer (two layers below the overwintering layer, $1347.5 \sim 1352.5$ m elevation) by cooling pipe in the dam. Water temperature range from $20^{\circ} \mathrm{C}$ to $23^{\circ} \mathrm{C}$, water continued for 7 days (from new concrete 7 days after construction resume to pouring end), and return to construction in late-April.

Scheme III: Taking all measures of Scheme II, and return to construction in mid-May.

According to the concrete construction record of sediment storage dam, insulation measures during overwintering period and thermodynamics parameters of concrete, 3-D finite element simulation on the three different schemes of crack prevention measures at overwintering layer was calculated. The calculation results were listed in table 8 12.

Table 8 The highest temperature results of new concrete after return to construction

\begin{tabular}{c|c|c|c|c|c|c}
\hline Scheme & \multicolumn{2}{|c|}{ I } & \multicolumn{2}{c}{ II III } \\
Position & $\begin{array}{c}1352.5 \sim \\
1355.5 \mathrm{~m}\end{array}$ & $\begin{array}{c}1355.5 \sim \\
1358.5 \mathrm{~m}\end{array}$ & $\begin{array}{c}1352.5 \sim \\
1355.5 \mathrm{~m}\end{array}$ & $\begin{array}{c}1355.5 \sim \\
1358.5 \mathrm{~m}\end{array}$ & $\begin{array}{c}1352.5 \sim \\
1355.5 \mathrm{~m}\end{array}$ & $\begin{array}{c}1355.5 \sim \\
1358.5 \mathrm{~m}\end{array}$ \\
\hline Highest temperature of RCC & $18.8^{\circ} \mathrm{C}$ & $19.4^{\circ} \mathrm{C}$ & $19.4^{\circ} \mathrm{C}$ & $19.9^{\circ} \mathrm{C}$ & $20.9^{\circ} \mathrm{C}$ & $21.7^{\circ} \mathrm{C}$ \\
\hline Allowable temperature of RCC & $23^{\circ} \mathrm{C}$ & $23^{\circ} \mathrm{C}$ & $23^{\circ} \mathrm{C}$ & $23^{\circ} \mathrm{C}$ & $23^{\circ} \mathrm{C}$ & $23^{\circ} \mathrm{C}$ \\
\hline Meet requirements? & Yes & Yes & Yes & Yes & Yes & Yes \\
\hline Highest temperature of normal concrete & $24.4^{\circ} \mathrm{C}$ & $26.4^{\circ} \mathrm{C}$ & $24.6^{\circ} \mathrm{C}$ & $26.6^{\circ} \mathrm{C}$ & $25.8^{\circ} \mathrm{C}$ & $28.1^{\circ} \mathrm{C}$ \\
\hline Allowable temperature of normal concrete & $28.5^{\circ} \mathrm{C}$ & $28.5^{\circ} \mathrm{C}$ & $28.5^{\circ} \mathrm{C}$ & $28.5^{\circ} \mathrm{C}$ & $28.5^{\circ} \mathrm{C}$ & $28.5^{\circ} \mathrm{C}$ \\
\hline Meet requirements? & Yes & Yes & Yes & Yes & Yes & Yes \\
\hline
\end{tabular}

Table 9 The upper and lower temperature difference results of RCC at overwintering layer

\begin{tabular}{c|c|c|c|c|c|c}
\hline Scheme & \multicolumn{2}{|c|}{ I } & \multicolumn{2}{c}{ II } & \multicolumn{3}{c}{ III } \\
\hline Position & $1352.5 \mathrm{~m}$ & $1355.5 \mathrm{~m}$ & $1352.5 \mathrm{~m}$ & $1355.5 \mathrm{~m}$ & $1352.5 \mathrm{~m}$ & $1355.5 \mathrm{~m}$ \\
\hline Highest average temperature of upper layer & $18.1^{\circ} \mathrm{C}$ & $18.8^{\circ} \mathrm{C}$ & $18.4^{\circ} \mathrm{C}$ & $19.3^{\circ} \mathrm{C}$ & $20.2^{\circ} \mathrm{C}$ & $21.0^{\circ} \mathrm{C}$ \\
\hline Average temperature of lower layer & $5.5^{\circ} \mathrm{C}$ & $14.0^{\circ} \mathrm{C}$ & $10^{\circ} \mathrm{C}$ & $14.0^{\circ} \mathrm{C}$ & $9.5^{\circ} \mathrm{C}$ & $16.0^{\circ} \mathrm{C}$ \\
\hline Upper and lower temperature difference & $12.6^{\circ} \mathrm{C}$ & $4.8^{\circ} \mathrm{C}$ & $8.4^{\circ} \mathrm{C}$ & $5.3^{\circ} \mathrm{C}$ & $10.7^{\circ} \mathrm{C}$ & $5.0^{\circ} \mathrm{C}$ \\
\hline Allowable value & $15^{\circ} \mathrm{C}$ & $15^{\circ} \mathrm{C}$ & $15^{\circ} \mathrm{C}$ & $15^{\circ} \mathrm{C}$ & $15^{\circ} \mathrm{C}$ & $15^{\circ} \mathrm{C}$ \\
\hline Meet requirements? & Yes & Yes & Yes & Yes & Yes & Yes \\
\hline
\end{tabular}

Table 10 The upper and lower temperature difference results of normal concrete at overwintering layer

\begin{tabular}{c|c|c|c|c|c|c}
\hline Scheme & \multicolumn{2}{|c|}{ I } & \multicolumn{3}{c}{ II } & \multicolumn{3}{c}{ III } \\
\hline Position & $1352.5 \mathrm{~m}$ & $1355.5 \mathrm{~m}$ & $1352.5 \mathrm{~m}$ & $1355.5 \mathrm{~m}$ & $1352.5 \mathrm{~m}$ & $1355.5 \mathrm{~m}$ \\
\hline Highest average temperature of upper layer & $23.5^{\circ} \mathrm{C}$ & $25.5^{\circ} \mathrm{C}$ & $23.8^{\circ} \mathrm{C}$ & $25.8^{\circ} \mathrm{C}$ & $24.9^{\circ} \mathrm{C}$ & $26.5^{\circ} \mathrm{C}$ \\
\hline Average temperature of lower layer & $5.5^{\circ} \mathrm{C}$ & $19.0^{\circ} \mathrm{C}$ & $9.5^{\circ} \mathrm{C}$ & $19.0^{\circ} \mathrm{C}$ & $9.0^{\circ} \mathrm{C}$ & $20.0^{\circ} \mathrm{C}$ \\
\hline Upper and lower temperature difference & $18^{\circ} \mathrm{C}$ & $6.5^{\circ} \mathrm{C}$ & $14.3^{\circ} \mathrm{C}$ & $6.8^{\circ} \mathrm{C}$ & $15.9^{\circ} \mathrm{C}$ & $6.5^{\circ} \mathrm{C}$ \\
\hline Allowable value & $16^{\circ} \mathrm{C}$ & $16^{\circ} \mathrm{C}$ & $16^{\circ} \mathrm{C}$ & $166^{\circ} \mathrm{C}$ & $16^{\circ} \mathrm{C}$ & $16^{\circ} \mathrm{C}$ \\
\hline Meet requirements? & No & Yes & Yes & Yes & Yes & Yes \\
\hline
\end{tabular}


The table 8 shows that the scheme I II and III can all meet the demands of concrete highest temperature. Compare the analysis of upper and lower temperature difference results in table 9 with that in table 10, it can be found that the upper and lower temperature differences in three different schemes can all meet the demands of control standards. But in scheme I, the upper and lower temperature difference of normal concrete at overwintering layer reaches $18^{\circ} \mathrm{C}$ which already exceeds allowable temperature difference standard. The reasons are as follows. Because of the low air temperature during overwintering intermittence period, the insulation measures have been taken at sides and top surfaces of concrete, however, average temperature of overwintering concrete is still low as cold lasts a long time when it return to construction next year. In addition, highest temperature of the new concrete after construction resume lead to the exceeding of upper and lower temperature difference because the hydration heat of normal concrete is high. In scheme II, the pre-heating treatment measure is taken on overwintering concrete. Then the average temperature of lower concrete is raised and the upper and lower temperature difference is reduced. In scheme III, the construction resume time is put off until mid-May when the temperature of old concrete rises at overwintering position, so it benefits reducing the upper and lower temperature difference. As a consequence, the upper and lower temperature differences of normal concrete and RCC concrete can all meet their allowable standards.

Table 11 Vertical tensile stress results at overwintering layer (Unit: MPa)

\begin{tabular}{|c|c|c|c|c|c|c|}
\hline Scheme & \multicolumn{2}{|r|}{ I } & \multicolumn{2}{|c|}{ II } & \multicolumn{2}{|c|}{ III } \\
\hline Position & \multicolumn{2}{|c|}{$1352.5 \mathrm{~m}$} & \multicolumn{2}{|c|}{$1352.5 \mathrm{~m}$} & \multicolumn{2}{|c|}{$1352.5 \mathrm{~m}$} \\
\hline Concrete & $\mathrm{RCC}$ & Normal concrete & $\mathrm{RCC}$ & Normal concrete & $\mathrm{RCC}$ & Normal concrete \\
\hline Max tensile stress & 1.13 & 1.59 & 0.99 & 1.45 & 1.06 & 1.5 \\
\hline Time & \multicolumn{6}{|c|}{ the second winter } \\
\hline Age of concrete & \multicolumn{6}{|c|}{$180 \mathrm{~d}$} \\
\hline Allowable value & 1.09 & 1.52 & 1.09 & 1.52 & 1.09 & 1.52 \\
\hline Meet requirements? & No & No & Yes & Yes & Yes & Yes \\
\hline
\end{tabular}

The Table 11 shows that in scheme I, the maximum tensile stress of RCC concrete at overwintering position is $1.13 \mathrm{MPa}$ and that of normal concrete is $1.71 \mathrm{MPa}$, both of them exceed the maximum allowable vertical stress at overwintering joint position. In scheme II, the maximum tensile stress of RCC concrete at overwintering position is $0.99 \mathrm{MPa}$ and that of normal concrete is $1.45 \mathrm{MPa}$, both of them can meet requirement of the maximum allowable vertical stress. In scheme III, the maximum tensile stress of RCC concrete at overwintering position is $1.06 \mathrm{MPa}$ and that of normal concrete is $1.50 \mathrm{MPa}$, both of them can meet requirement of the maximum allowable vertical stress.

Table 12 The tensile stress results of new concrete after return to construction of Scheme II (Unit: MPa)

\begin{tabular}{c|c|c|c|c}
\hline Scheme & \multicolumn{4}{|c}{ II } \\
\hline Position & \multicolumn{2}{|c|}{$1352.5 \sim 1355.5 \mathrm{~m}$} & \multicolumn{3}{c}{$1355.5 \sim 1358.5 \mathrm{~m}$} \\
\hline Concrete & RCC & Normal concrete & Normal concrete \\
\hline Max tensile stress & 1.36 & 1.76 & 1.44 & 1.91 \\
\hline Time & \multicolumn{5}{|c|}{ the second winter } \\
\hline Age of concrete & \multicolumn{3}{|c|}{$180 \mathrm{~d}$} & 1.66 \\
\hline Allowable value & 1.66 & 2.09 & Yes & 2.34 \\
\hline Meet requirements? & Yes & Yes & Yes \\
\hline
\end{tabular}

The table $12 \& 13$ shows that the maximum internal tensile stresses of new normal concrete are $1.91 \mathrm{MPa}$ and 2.03MPa after construction resume in scheme I and II. Those of new RCC concrete are 1.44MPa and 1.52MPa. The maximum tensile stresses all appear in cold of next (in 2012) winter, but they can all meet their allowable tensile stress standards. 
Table 13 The tensile stress results of new concrete after return to construction of Scheme III (Unit: MPa)

\begin{tabular}{|c|c|c|c|c|}
\hline Scheme & \multicolumn{4}{|c|}{ III } \\
\hline Position & \multicolumn{2}{|c|}{$1352.5 \sim 1355.5 \mathrm{~m}$} & \multicolumn{2}{|c|}{$1355.5 \sim 1358.5 \mathrm{~m}$} \\
\hline Concrete & $\mathrm{RCC}$ & Normal concrete & $\mathrm{RCC}$ & Normal concrete \\
\hline Max tensile stress & 1.43 & 1.85 & 1.52 & 2.03 \\
\hline Time & \multicolumn{4}{|c|}{ the second winter } \\
\hline Age of concrete & \multicolumn{4}{|c|}{$180 \mathrm{~d}$} \\
\hline Allowable value & 1.66 & 2.09 & 1.66 & 2.34 \\
\hline Meet requirements? & Yes & Yes & Yes & Yes \\
\hline
\end{tabular}

Through the crack prevention simulation of scheme I, II and III, the scheme II and III are all feasible at overwintering position after construction resume from the perspective of highest temperature, upper and lower temperature difference, allowable vertical tensile stress and allowable tensile stress. The scheme III of crack prevention measures at layer position is selected in this project because the preparation workload is heavy before construction resume after overwinter.

\section{The effect of crack prevention measures at overwintering layer}

According to the measured data of thermometers which are embedded below the overwintering insulating layer (elevation $1352.5 \mathrm{~m}$ ), minimum temperature at the boundary was $6.5^{\circ} \mathrm{C}$ and that in the middle of overwintering layer was $7.6^{\circ} \mathrm{C}$ during the overwinter from 2011 to 2012 . The waterproof clothes with cornstalks, straws, polystyrene insulation $(2.5 \mathrm{~cm}$ thick $)$ and polystyrene insulation $(2.5 \mathrm{~cm}$ thick) were gradually removed (the average time interval is 4 days) from April after overwinter. Large-area cracks were not founded after uncovering all the heat preservation covering when the top of overwintering concrete are checked. Only three short cracks were founded in dam segment of left bank slope. The preliminary reasons are as follows: because of the seepage at cofferdam and pit, the winter drainage canal was arranged at left bank slope next to dam segment slope. The large flow in drainage canal and low temperature of water lead to "Cold Shock Effect" in dam segment of left bank slope and then concrete cracked.

The sediment storage dam continue to pour concrete in mid-May 2012, the measures including pipe cooling, pouring temperature control and intermittence control were taken on the basis of commendatory crack prevention measures. Horizontal crack was not founded at overwintering position through the test of winter from 2012 to 2013 . It is observed that the commendatory crack prevention measures of sediment storage dam at overwintering layer in Hohhot pumped storage power station are feasible.

\section{Summary}

This paper takes the sediment storage dam of the down reservoir of Hohhot pumped storage power station as a case, the heat preservation and crack control measures of overwintering area have been analyzed. The reasonable and feasible heat preservation measures have been determined by the simulation analysis on different heat preservation scheme from the inside and outside temperature difference and allowable tensile stress angle, and after winter severe cold test, this preservation measures work well. After overwintering period, the construction of the dam continues. In order to avoid the cracks in bonding zone between old and new concrete layers, the reasonable and feasible crack control measures have been determined by the simulation analysis on different crack prevention measures from the highest temperature, upper and lower temperature difference, vertical stress and allowable tensile stress angle. After winter severe cold test, cracks in bonding zone do not happen, and this crack control measures work well. 
The overwintering problem about heat preservation and crack prevention in bonding zone should be given particular attention. The implementation of heat preservation and crack control measures of overwintering layer concrete of the sediment storage dam of the down reservoir of Hohhot pumped storage power station works well, which can provide a reference for the similar problems in other engineering.

\section{References}

[1] W.W. Cai, Discussion on temperature control and crack prevention of RCC dam, Advances in Science and Technology of Water Resour. 20 (2) 28-30. (2000)

[2] B.F. Zhu, Thermal stresses and temperature control of mass concrete, China Electric Power Press, Beijing, 1999.

[3] B.F. Zhu, Current situation and prospect of temperature control and cracking prevention technology for concrete dam, J. of Hydraulic Engineering. 37 (12) 1424-1431. (2006)

[4] J.Z. Wei, et al., Design specification for hydraulic concrete structures, China Electric Power Press, Beijing, 2009.

[5] Z.H. Han, Design specification for concrete gravity dams, China Electric Power Press, Beijing, 1999. 